\title{
Users' expectations about the practice of nurses in a Psychosocial Care Center*
}

\author{
Expectativas de usuários sobre a prática de enfermeiros de um Centro de Atenção \\ Psicossocial
}

Débora Biffi ${ }^{1}$, Cintia Nasi ${ }^{2}$

Objective: to understand users' expectations about the practices of nurses from a Psychosocial Care Center, Alcohol, and Other Drugs. Methods: this is a qualitative study that used the theoretical-methodological reference of phenomenological sociology. It was developed in a Psychosocial Care Center, Alcohol and other Drugs, in which 15 users were interviewed. Results: through this research, it was seen the expectations of the users about the nurses involved in their treatments, and it is possible to verify that they considered the nurses a fundamental part of the therapeutic process. Users have shown that the bonding relationship between them and the nurses is a way to strengthen and empower their involvement with the treatment. Conclusion: the users demonstrated that they have the expectation of creating a bond of trust with the nurses, considering them as professionals able to offer assistance, guidance, and contingency for fears and anxieties.

Descriptors: Mental Health; Nursing; Drug Users.

Objetivo: compreender as expectativas de usuários sobre as práticas de enfermeiros de um Centro de Atenção Psicossocial Álcool e outras Drogas. Métodos: estudo qualitativo, que utilizou o referencial teórico-metodológico da sociologia fenomenológica. Desenvolvido em um Centro de Atenção Psicossocial Álcool e outras Drogas, em que foram entrevistados 15 usuários. Resultados: através desta pesquisa vislumbramos as expectativas dos usuários sobre os enfermeiros envolvidos em seus tratamentos, sendo possível constatar que os usuários consideravam os enfermeiros parte fundamental do processo terapêutico. Os usuários demonstraram que a relação de vínculo que surge entre eles e os enfermeiros é uma maneira de fortalecer e potencializar o seu envolvimento com o tratamento. Conclusão: os usuários demonstraram expectativa da criação de vínculo de confiança com os enfermeiros, considerando-os como profissionais capazes de oferecer assistência, orientações e contingência para medos e angústias.

Descritores: Saúde Mental; Enfermagem; Usuários de Drogas.

\footnotetext{
*Extracted from the dissertation “Centro de Atenção Psicossocial Álcool e outras Drogas sob a ótica do usuário: subsídios para a qualificação da consulta de enfermagem", Universidade do Vale do Rio dos Sinos, 2014.

${ }^{1}$ Universidade do Vale do Rios dos Sinos. Porto Alegre, RS, Brazil.

${ }^{2}$ Universidade Federal de Ciências da Saúde de Porto Alegre. Porto Alegre, RS, Brazil.

Corresponding author: Débora Biffi

Av. Protásio Alves, 7355 - Petrópolis, CEP: 91310-003. Porto Alegre, RS, Brazil. E-mail: biffidebora@yahoo.com.br
} 


\section{Introduction}

The for Psychosocial Care Center, Alcohol and Drugs is a unit of care and monitoring of mental health, with a multi-professional team composed of a physician, a nurse, a psychologist, an occupational therapist, a social worker, nursing technicians, among other professionals who perform individual, group and home visits ${ }^{(1)}$. This type of service is distinguished by specialized care for people who use of abuse and dependence harmful substances, performing clinical follow-up, promoting the reinsertion of the user into society and encouraging the reconstruction of their autonomy ${ }^{(2)}$.

In this sense, it becomes indispensable that the users feel part of this process and welcomed by the team of professionals of the health service. Understanding the expectations of the users regarding the treatment offered by the Psychosocial Care Center team on alcohol and other drugs, especially regarding nurses, allows a greater understanding of their perceptions and analysis of the care provided from the needs expressed by the users.

Observing and analyzing the relationships of users, family members, and treatment are indispensable for understanding the evolution and historical adaptation of mental health in Brazil. Therefore, it is essential to give them time and voice to provide better assistance to the user, so that they express themselves on the attention paid and the way they see this attention, contributing to the qualification of the assistance in the Psychosocial Care Centers.

When observing the uniqueness of the therapeutic process that the users of the Psychosocial Care Center Alcohol and other Drugs are inserted, the questioning inherent to this research has arisen: what expectations do the users of a Psychosocial Care Center Alcohol and other Drugs have about the practices developed by nurses of this service? Thus, giving voice to the users' experiences, there were broaden care approaches, strengthening the behaviors, experiences, and practices of nursing professionals.
This study becomes relevant, given the construction and consolidation of substitutive services, such as the Psychosocial Care Centers and the requirement to pay more attention to the needs highlighted by the users. Also, it is fundamental that the nursing, in these services, developing skills and instruments to qualify their professional practice. The objective of this research was to understand the expectations of users about the practices of nurses from a Psychosocial Care Center, Alcohol, and Other Drugs.

\section{Methods}

This qualitative study used the theoretical-methodological reference of phenomenological sociology. It was carried out at the Psychosocial Care Center, Alcohol and other Drugs III, connected to the Conceição Hospital Group of the city of Porto Alegre, state of Rio Grande do Sul, Brazil. The study participants were 15 users being treated at the service, who were chosen for convenience. The sample for convenience involves the use of the most conveniently available people as participants ${ }^{(3)}$. Subsequently, the interviews were scheduled according to the availability of the user, and the interviews were conducted, at the Psychosocial Care Center. The staff of the Psychosocial Care Center helped in the invitation to the users and their approach. The inclusion criteria used to collect the information were: users being treated in the service, aged over 18 years old, who had been under treatment for at least three months. The exclusion criteria adopted were: users with exacerbations of symptoms that made verbal communication difficult at the time of the interview, as well as users in psychomotor agitation and severe abstinence syndrome.

The collection of information began with a characterization of theusersand the phenomenological interview, with a semi-structured script, in which the guiding questions were: 1) Tell me how is your care here at the Psychosocial Care Center. 2) Tell me what do you expect from the professional nurse during 
your treatment. The interviews were recorded using a digital voice recorder and later transcribed in full with minimal interference from the interviewer.

The information collected was subjected to phenomenological analysis, according to researchers of social phenomenology, through the following steps $\left.^{(4-5)}: 1\right)$ reading and re-reading the contents of the speeches to obtain the essence of the meanings of the interpretations of the users about their treatment; 2) identify excerpts from the speeches that represent the perception about the practice of the nurse offered to the users in the for Psychosocial Care Center, Alcohol, and other Drugs; 3 ) group the common aspects of the units of meaning, that is, the convergences that allow the emergence of the concrete categories about users' expectations about nurses' practices. In the presentation of the results and discussion of the thematic categories, the use of a referential of the mental health area and the reference of Alfred Schutz was prioritized.

The study complied with the formal requirements contained in the national and international regulatory standards for research involving human beings.

\section{Results}

\section{Users' expectations regarding the nurses at the for Psychosocial Care Center Alcohol and Other Drugs}

The users of the Psychosocial Care Center alcohol and other drugs, participants of this study, reported on the expectations regarding the practices developed by the service nurses. Then, they can talk more with us, so we can tell our story, sometimes we have relapses, so they can talk more. They guide me, if in case I see that I am wrong, if I ask, if they see that I am really sick even, I ask a for a hosting (E01). The nurse has knowledge of everything to be a doctor, it is a small thing and if it depended on me, ten points for them, because they care about us, want to know and such, can talk about something that we do not know about our problem (E02).

The users perceive the importance of the presence of the nurse during the therapeutic process, being inserted in the groups, activity, and individual care, acting as a communicator, mediating the family relationships and, mainly, demonstrating support to the user during the treatment. I think that when the person chooses to be a nurse, they have to like people, so I always expected this from the nurses, treating us like that, with a certain kindness, with a certain understanding (E04). I think if the nurse talked more, we had that greater bond with the nurse, you know, about the medication. Take care of a little more user's behavior, do not get so cold, so sometimes isolated in their computer seat and take a look from time to time so, see who is almost falling, who is not taking medication (E08).

Although users reported satisfaction with the treatment of nurses, there were users who scored the need for nurses to have more time to listen/talk with them. Thus, users believe that nurses can collaborate, through conversations and moments of listening, with the relief of negative symptoms that arise during the therapeutic process, recognized the nurses as professionals endowed with knowledge capable of providing pertinent guidance to their moment of suffering and anguish: The role of nurses, yes. They have to put an order in the place, have to take care of users, schedule things, it is very hard. If they had more time with us, it would be very good, to talk and listen to people, to be more together. Yeah, he had one, he is not even here anymore, he was kind of stupid. So, they had a meeting, no one wanted more, then left. (E09). They are always worried, talking, touching, teaching us, opening our eyes, we see that it is not false, right. That depends on me, I also have to help myself(E14).

The interviewed users demonstrated the establishment of bond with the nursing professionals of the Psychosocial Care Center, referring to the nurses as professionals who were interested in helping them in the treatment. What I have to say of the nurses are very dedicated because I look surprised I sometimes think that it is only for the salary and not, and there are people who are beyond the salary, gives more strength, help you (E03). So, their conversations always push me forward, they help us organize ideas, they care about us. It is giving me a fissure, so to fall. But think about it, man, you are here to treat you, it is already a few days, it is already nice, the body is still so clean (E04). 
The users also demonstrated confidence in the treatment offered by the professional nurses in the Psychosocial Care Center. The relationship between nurse and user is very important to a treatment for whatever it is because you feel, here in the Psychosocial Care Center I feel the confidence, I have the confidence of what they are doing, of what they say, the way they act in everything, the medication... of my life. So, I have a lot of confidence in the treatment of them here, the nursing staff in general, to this and the attention they give us because we are in a difficult situation, vulnerable, because it is giving up certain pleasures in quotation marks that bring the alcohol and the life outside, to heal, to treat, to get better life, because it is not a good life (E05).

The interviewees when referring to nurses, highlighted a relationship of trust, respect, concern with the life of the user and advice regarding the treatment of users. The nurses want to know what you look like. How's your house? Because they say our home is important too, these conversations with them, ours are very good and they help a lot. She gives me advice, because I also have a problem at home, because my father is an alcoholic, and then she said to me, she said: "Oh, bring your father to family reunions, who knows, he goes alone, so we will analyze him, maybe even help him (E13). The nurses try to talk that my change would have to be from the inside out, not just stop and give. That I would have to have several modifications, that I have a lot of defects still and here I am still learning to correct these errors and the importance of the nurses is this, that they encourage us, that there are nurses that stay in there, they are more closed and there are some who are more open, they play with us, so I think that we have to respect both of them anyway, but there are nurses there who are wonderful (E15).

\section{Discussion}

The limits of the results of this study are related to the investigation with users of a specific mental health service, and the data cannot be generalized to all Psychosocial Care Centers in the country. In this research, it was chosen the phenomenological method of Alfred Schutz, in which we do not look for generalizations that can be transported to other scenarios but to understand the typical characteristics of a certain social group, in this case, with users of a mental health service in the region South of Brazil.

The study presented its contribution with the results found in the research by explaining the expectations that the users have with the nurses of the service, being marked by the importance of the therapeutic role of the nurses and with the expectation of creating a bond with these professionals. Such characteristics can guide the performance of nursing in this service modality, demonstrating the importance of therapeutic communication, listening and bonding in the treatment of users of alcohol and other drugs.

In Phenomenological Sociology, a sociology of knowledge was founded, starting from the common sense of daily life and the cognitive processes through which it is established and applied, considering intersubjectivity as a data inserted in the social world on which any activity is built. It is necessary to apprehend them by the code of human reasons, ends and means, planning, and finally, the categories of human action to understand social phenomena ${ }^{(6)}$.

In this way, human motivations are characterized by groups of interconnected factors originating from personalities, which will define the behavior of each one at a given moment. Because they are interconnected, these factors involving personality, cultures, experiences as a whole, begin to demonstrate a motivational behavior when they come into action, in which the individual uses feelings, instincts and lived experiences in the pursuit of a certain goal ${ }^{(7)}$. The action is interpreted by the subject based on their existential motives, derived from their experiences. The motivations related to the achievement of objectives, expectations and projects are the reasons and those related to the stock of knowledge and in the experiences of the subjects are called motives ${ }^{(8)}$.

The users had the motivation, the expectation of developing a therapeutic communication with the nurses of the service. Communication for the nursing professional is not a constant phenomenon, but it is formed by an articulated network of personal, family and institutional information and relationships that are interconnected and feedback ${ }^{(9)}$. In this, users 
transmit fears and concerns, and the nurse absorbs such information and transmits new information to the user, with discretion and delicacy, respecting the existing bond between the two of them. Thus, effective communication requires understanding of the user and his/her experiences, as well as the sincere skills and intentions of both parties, user/nurse, so that there is an understanding of the phenomenon experienced $^{(10)}$.

In this sense, as communication is an indissoluble phenomenon of nursing care for any service to the user, they attribute directly to the nurse and the communicator characteristic. The users perceived the importance of the presence of the nurse during the therapeutic process, being inserted in the groups, activities and individual attendances, acting as communicator, mediating the family relationships and, mainly, demonstrating support to the user during the treatment.

During his/her existence, each user interprets the world inserted in an optics where the own interests, reasons, desires, ideological and religious commitments are taken as truth. However, the reality how these forms manifest in daily life depends on the sum of experiences that the user constructs in the development of his massive existence, adding values to these experiences ${ }^{(11)}$. The users demonstrated the manifestation of their motivation, externalizing their intentions as what they expect from the nurses of the service.

Regarding the nurses' listening in the service, the users pointed out that they felt the need for nurses to have more time to listen/talk with them. In this way, social phenomenology is revealed as a new possibility to think, restructure and practice the nursing care actions, establishing as a starting point of the social relationships created in the world of life, that is, giving voice to the experiences of each user ${ }^{(11)}$.

Nursing is a human science, made up of people and their experiences, so the nurse, in addition to executing and guaranteeing a humanized nursing care based on scientific knowledge for its clients, is also a communicator and facilitator of the therapeutic processes $^{(10)}$. The nurse, by taking over communication, especially listening, as an indispensable tool for the development of her work can guarantee an individualized assistance, with greater effectiveness, and strengthening the adherence and satisfaction of the user.

Listening is one of the abilities inherent in human beings, and the conception of listening is commonplace as just listening, leading one to believe that listening is merely an instinctive activity. It is important to note that listening is an essential tool for the user to be treated in the perspective of care as an integral action, which accesses the subjective human field, since for the suffering subject, it can mean problem-solving, availability, understanding, trust and respect ${ }^{(12)}$.

It is believed that caring is the essence of nursing, permeated by values that aim for respect and love of others. The priority of nursing will always be to promote the health and well-being of the user, regardless of the service where this care is being developed. The process of development of humanized care seeks a qualified health care in an integral way, which enables an adequate listening and an expansion of the care optics ${ }^{(11)}$.

Drug use is considered a growing problem of public health, which has repercussions on family, cultural patterns and the economy. Nursing occupies a prominent place in attention to users of alcohol and other drugs, given the very characteristics of care of the profession and the proximity with families. Thus, nurses' attitudes, such as therapeutic communication, may have repercussions on the quality of care provided to these users ${ }^{(13)}$.

The users pointed out the establishment of bond that they have with the nurses of the service, which contributes to their treatment. Human relationships begin with the establishment of a bond that enables the constitution of the process of trust. 
The construction of the health bond is dependent on the way health teams become a fundamental part of the therapeutic process of the users inserted in the health services of a certain group. Moreover, the linkage of users with health services needs the establishment of strong interpersonal ties that represent the mutuality between health professionals and users ${ }^{(14)}$.

One of the factors that act as a fundamental facilitator for nursing linkages is the power to communicate. Communication emerges for nursing as a basic tool for the development of care, it is present in the actions developed with the users, to provide guidance, support, comfort or meeting basic needs. Thus, using communication as a basic tool, the nurse can understand significantly the needs of the users and to provide care, listening and more effective assistance in the development of care ${ }^{(15-16)}$.

Regarding the hosting, it is important to note that from this point of view, the creation of listening moments, the development of a social relationship and the possibility of individualized attention, according to the needs of the users. It is possible to observe that the users of the study reported the importance given by them to the interpersonal relationships and to the moments of conversations with the professional nurses. The host seeks to promote the change of the work process to meet all those who seek health services, aiming at the health needs of users. It proposes a redirection of actions, promoting the integration of knowledge and practices, increasing its solvency ${ }^{(17)}$.

The act of caring for others includes performing technical procedures based on attitudes guided by humanized principles, including respect for the user. We can affirm that the provision of care directed to care is directly linked to the professional, personal, personality and care of the caregiver and the user, acquired through experiences, and cultural beliefs ${ }^{(17)}$. Regardless of the type of care provided by nurses in any health service, it is essential that they show empathy for the user's suffering, which provides greater delivery by the users, which reduces the number of treatment abandonments.

The therapeutic process coming from the communication between nurse/user is denominated as therapeutic communication, which has the purpose of understanding, identifying and meeting the health needs of the user, contributing to provide personalized assistance, improving nursing practice. When we create opportunities for the development of learning and strengthen interpersonal relationships, we awaken in the users' feelings of trust, allowing them to feel welcomed, satisfied and secure ${ }^{(15)}$.

The term trust, referred by the users, suggests the process resulting from the individual perception of the user regarding the provision of care, care by a nurse. Then, when personalizing care, we assume, in a way and of relevance, a moment of exchanges, favoring the empowerment of the user about his/her state $^{(16)}$. Study users demonstrate that trusting them is relative, variable, and personal. Trust is not always attributed to the same nursing professional, because it is considered to build this trust, the particularities of each user, the empathy developed during the initial reception and the experiences of each involved.

The formulation of trust is an interactive process, in which nurses and users are allied actors for this construction. Nurses play an important role in the development of this trust, since it represents the basic tool of this therapeutic instrument in the relationship of caring, and it is essential that it be performed competently, grounding its actions in ethical, scientific and technical knowledge ${ }^{(15)}$. Despite being very important to interpersonal relationships, users are attentive and critical about the level of knowledge and commitment of nurses, being indispensable to constant updating, to provide support to individual therapies and groups developed by the service, linking these to the reality of each user.

It is considered that when using interpersonal relationships as a privileged tool for the development of work, nurses should seek permanent and 
differentiated methods for developing their skills. Confidence is formed by sensitive connections, and limitation can make these impersonal relationships distant and conflicting, making the therapeutic processes more effective and strengthening the bonds ${ }^{(18)}$.

\section{Conclusion}

The users demonstrated that they had an expectation of a relationship of trust with the nursing professional, and they saw this professional as someone who could provide him with the necessary assistance and guidance, a safe place for fears and anguishes common to the treatment of abuse and dependence of alcohol and other drugs.

\section{Collaborations}

Biffi D and Nasi C contributed in designing the project, analyzing, interpreting the data, writing the article and critically reviewing the relevant intellectual content and approving the final version to be published.

\section{References}

1. Monteiro CFS, Fé LCM, Moreira MAC, Albuquerque IEM, Silva MG, Passamani MG. Perfil sociodemográfico e adesão ao tratamento de dependentes de álcool em CAPS-ad do Piauí. Esc Anna Nery. 2011; 15(1):90-5.

2. Araújo NB, Marcon SR, Silva NG, Oliveira JRT. Perfil clínico e sociodemográfico de adolescentes que permaneceram e não permaneceram no tratamento em um CAPS-ad de Cuiabá/MT. J Bras Psiquiatr. 2012; 61(4):227-34.

3. Polit DF, Beck CT. Fundamentos de pesquisa em enfermagem: avaliação de evidências para a prática da enfermagem. Porto Alegre: Artmed; 2011.
4. Macedo S, Caldas MT. Uma análise crítica sobre técnicas de pesquisa fenomenológica utilizadas em Psicologia Clínica. Rev NUFEN [Internet]. 2011 [citado 2016 jul. 14];3(1):3-16. Disponível em: http://www.scielo.br/pdf/estpsi/v28n2/03.pdf

5. Branco PC. Diálogo entre análise de conteúdo e método fenomenológico empírico: percursos históricos e metodológicos. Rev Abordagem Gestalt [Internet]. 2014 [citado 2016 jan. 27];20(2):189-97. Disponível em: http://pepsic. bvsalud.org/pdf/rag/v20n2/v20n2a06.pdf

6. Zeferino MT, Carraro TE. Alfred Schütz: from theoretical-philosophical framework to the methodological principals of phenomenological research. Texto Contexto Enferm. 2013; 22(3):82634.

7. Bezerra FD, Andrade MFC, Andrade JSA, Vieira MJ, Pimente D. Motivação da equipe e estratégias motivacionais adotadas pelo enfermeiro. Rev Bras Enferm. 2010; 63(1):33-7.

8. Jesus MCP, Capalbo C, Merighi MAB, Oliveira DMO, Tocantins FR, Rodrigues BMRD, et al. The social phenomenology of Alfred Schütz and its contribution for the nursing. Rev Esc Enferm USP. 2013; 47(3):736-41.

9. Martinez EA, Tocantins FR, Souza SR. As especificidades da comunicação na assistência de enfermagem à criança. Rev Gaúcha Enferm. 2013; 34(1):33-44.

10. Kourkouta L, Papathanasiou IV. Communication in nursing practice. Mater Soc Med [Internet]. 2014 [cited 2016 Aug. 29];26(1):65-7. Available from: http://www.ncbi.nlm.nih.gov/pmc/articles/ PMC3990376/

11. Mongiovi VG, Anjos RCCBL, Soares SBH, Lago-Falcão TM. Reflexões conceituais sobre humanização da saúde: concepção de enfermeiros de Unidades de Terapia Intensiva. Rev Bras Enferm. 2014; 67(2):306-11.

12. Maynart WHC, Albuquerque MCS, Brêda MZ, Jorge JS. Qualified listening and embracement in psychosocial care. Acta Paul Enferm. 2014; 27(4):300-4. 
13. Jesús MM, Daniel HS, Elena SÁ, Francisco CA. Impacto de las actitudes de las enfermeras en la calidad de los cuidados en drogodependientes. Index Enferm . 2012; 21(4):214-8.

14 Garuzi M, Achitti MCO, Sato CA, Rocha SA, Spagnuolo RS. Acolhimento na Estratégia Saúde da Família: revisão integrativa. Rev Panam Salud Publica. 2014; 35(2):144-9.

15. Pontes AC, Leitão IMTA, Ramos IC. Comunicação terapêutica em Enfermagem: instrumento essencial do cuidado. Rev Bras Enferm. 2011; 61(3):312-8.
16. Lourenço C, Pinto A, Pereira C, Fonseca C, Nunes I, Almeida MP, et al. Confiança versus desconfiança na relação de cuidar: confiança enfermeirocliente, um conceito em construção no CHLNHPV. Rev Pensar Enferm [Internet]. 2011 [citado 2016 mai. 11]; 15(2):3-13. Disponível em: http:// pensarenfermagem.esel.pt_2sem_3_13.pdf

17. Minoia NP, Minozzo F. Acolhimento em saúde mental: operando mudanças na Atenção Primária à Saúde. Psicol Cienc Prof. 2015; 35(4):1340-9.

18. Formozo GA, Oliveira DC, Costa TL, Gomes AMT. As relações interpessoais no cuidado em saúde: uma aproximação ao problema. Rev Enferm UERJ. 2012; 209(1):124-7. 